\title{
Preharvest exposure to the sun influences postharvest responses of 'Hass' avocado fruit
}

\author{
Allan B. Woolf*, Judith H. Bowen, Ian B. Ferguson \\ The Horticulture and Food Research Institute of New Zealand, Private Bag 92169, Auckland, New Zealand
}

Received 18 June 1998; accepted 2 October 1998

\begin{abstract}
'Hass' avocados (Persea americana Mill.) exposed to direct sunlight (sun fruit) had diurnal temperature cycles with flesh tissue reaching as high as $43^{\circ} \mathrm{C}$ under ambient temperatures of $15-25^{\circ} \mathrm{C}$. The response of sun and shaded fruit to postharvest treatments differed significantly. External damage from hot water treatments of $50^{\circ} \mathrm{C}$ for up to $10 \mathrm{~min}$, was lower in sun fruit, particularly on the exposed side of the fruit. Similarly, while shaded fruit had high levels of external chilling injury when stored at $0.5^{\circ} \mathrm{C}$ for up to 28 days, the exposed side of the fruit was undamaged. Leakage of electrolytes from skin tissue from the exposed side of sun fruit did not increase during storage, while that from shaded fruit increased by about $60 \%$. In addition, for fruit ripened without storage, sun fruit took longer to ripen than shade fruit. Changes in heat shock protein (hsp) gene expression and specific protein bands reflected the diurnal temperature cycle, with up-regulation of hsp mRNA and synthesis of specific proteins at flesh temperatures $>30^{\circ} \mathrm{C}$. Thus, exposure of fruit to the sun results in high skin and flesh temperatures, and consequently reduced incidence of postharvest heat and chilling injuries. These beneficial effects are similar to those found following postharvest heat treatments. (C) 1999 Elsevier Science B.V. All rights reserved.
\end{abstract}

Keywords: Fruit ripening; Heat shock proteins; Persea americana Mill.; Shelf life; Chilling injury; Heat treatment; Electrolyte leakage

\section{Introduction}

Seasonal and daily temperature fluctuations may influence both rates of growth and final quality of fruits. External and internal tempera-

\footnotetext{
* Corresponding author. Tel.: + 69-9-815-4200; fax: + 649-815-4202; e-mail: awoolf@hort.cri.nz.
}

tures of fruit exposed to sunlight can be very high. In hot dry climates, with air temperatures well above $30^{\circ} \mathrm{C}$, melon (Schroeder, 1965) and grape (Kliewer and Lider, 1968) flesh temperatures can exceed $40^{\circ} \mathrm{C}$. However, even in temperate climates, apple fruit flesh can exceed $40^{\circ} \mathrm{C}$ with air temperatures of not more than $30^{\circ} \mathrm{C}$ (Ferguson et al., 1998). The effects of these high fruit tempera- 
tures on fruit growth and quality characteristics are largely unknown.

Avocado fruit grown under temperate conditions can withstand postharvest high temperature treatments. These treatments, when applied prior to low temperature storage, can reduce the incidence of chilling injury (Woolf et al., 1995; Florissen et al., 1996; Woolf, 1997), and could be employed as low temperature disinfestation protocols (Sanxter et al., 1994). In avocado fruit, as in mangoes and papaya, pretreatments of moderate heat $\left(\right.$ e.g. $\left.38^{\circ} \mathrm{C}\right)$, induce tolerance to the much higher temperatures necessary for insect killing (Paull and Chen, 1990; Jacobi and Giles, 1997; Woolf and Lay-Yee, 1997). One of the factors likely to be associated with such induced tolerance is the induction of heat shock proteins (hsps). These are stimulated in fruit by postharvest heat treatments of avocado (Woolf et al., 1995; Florissen et al. 1996; Woolf and Lay-Yee, 1997), tomato (Lurie and Klein, 1991), and papaya (Paull and Chen, 1990), and in apple (Ferguson et al., 1998), and papaya (Paull and Chen, 1990) fruit in the field with high flesh temperatures. If, as with apple, high fruit temperatures in the field increase hsp synthesis prior to harvest, then we might expect some influence of these preharvest temperatures on postharvest tolerance of fruit to both heat and low temperature treatments. A consequence could be that much of the variability observed in postharvest fruit responses may be explained by preharvest temperature history. There may be a relationship between postharvest thermotolerance and air temperatures experienced in the field 3 days prior to harvest of papaya (Paull, 1995). Apart from this, there has been little attention paid to specific effects on postharvest responses of high fruit temperatures in the field resulting from exposure to the sun.

We hypothesised that fruit from exposed positions on the tree would respond to both high and low postharvest temperature conditions differently from fruit from shaded positions not subject to frequent high temperatures from direct sunlight. Accordingly, we have measured the temperatures of sun and shade fruit in the field, and the effect of these temperatures on hsp genes and proteins and on the external quality of these fruit following low $\left(0.5^{\circ} \mathrm{C}\right)$, and high $\left(50^{\circ} \mathrm{C}\right)$ postharvest temperature treatments.

\section{Materials and methods}

\subsection{Fruit temperature and heat shock response (Expt 1)}

\subsubsection{Fruit temperature measurements}

Temperatures of 'Hass' avocado fruit grown at Mt Albert, Auckland, were monitored by inserting Squirrel thermister probes (CM-UU-V5-1; Grant Inc., Cambridge, UK) into the fruit at an angle such that the tip was $10 \mathrm{~mm}$ deep into the flesh. Temperature was logged every $10 \mathrm{~min}$ using Squirrel Data Loggers (Model 1206; Grant Inc., Cambridge). A hand-held infrared thermometer (Model 210, Everest Interscience, Tucson, USA) was used to determine the temperature of the external fruit surface.

Fruit temperatures were measured on shaded fruit ('shade fruit': fruit under the leaf canopy), and on north-facing fruit which were in direct afternoon sunlight ('sun fruit') at various times over the December-February period (mid-summer). Both exposed and unexposed sides of the sun fruit were monitored. Air temperature was measured by hanging a probe inside the tree canopy in total shade. In late February, duplicate fruit samples were taken at 12:00, 15:00, 20:00, and 08:00 $\mathrm{h}$ for analysis of protein synthesis and hsp mRNA. Continuous temperature measurements were made using two representative fruit, and when individual fruit were sampled, flesh temperatures were measured.

\subsubsection{Protein analysis and labelling}

A $13 \mathrm{~mm}$ diameter plug of fruit tissue was taken from an equatorial position, and the skin (exocarp; $\approx 0.5 \mathrm{~g}$ ) excised. A disk of flesh tissue (mesocarp; $\approx 0.5 \mathrm{~g}$ ) was then cut from the remaining outer part of the plug. Both flesh and skin disks were washed $(10 \mathrm{mM}$ ascorbate plus 1 $\mathrm{mM} \mathrm{CaCl}$ ), blotted dry and placed (in the case of the skin disk, cut surface facing upwards) in a petri dish on filter paper soaked in the wash solution. Carrier-free $\left[{ }^{35}\right.$ S $]$ methionine $(5 \mu 1,50$ 
$\mu \mathrm{Ci} ; 1220 \mathrm{Ci} \mathrm{ml}^{-1}$, New England Nuclear) was dropped onto the exposed surface and the disk incubated at room temperature $\left(\approx 20^{\circ} \mathrm{C}\right)$ for $2 \mathrm{~h}$. Tissue was stored at $-80^{\circ} \mathrm{C}$. Thereafter, the disk was ground in liquid $\mathrm{N}_{2}$ together with $20 \mathrm{mg}$ insoluble PVP. The powder was transferred to 0.5 ml $100 \mathrm{mM}$ Hepes, $\mathrm{pH}$ 8, containing $1 \mathrm{mM}$ PMSF and 0.1 mM DTT. The extract was ground further in a glass Kondes grinder, centrifuged at $12000 \times g$ for $2 \mathrm{~min}$, the supernatant removed, and 5 volumes of cold acetone added. After standing at $4^{\circ} \mathrm{C}$ overnight, the protein was washed with cold acetone and air-dried, then taken up in SDS sample buffer, separated by SDS-PAGE on $13 \%$ gels (equal protein cpm loaded), and autoradiographed (Ferguson et al., 1994).

\subsubsection{RNA extraction and northern analysis}

From the same area of the fruit that was sampled for protein, the skin and flesh tissue immediately below the skin were separately peeled into liquid $\mathrm{N}_{2}$ and stored at $-80^{\circ} \mathrm{C}$. Total RNA was extracted (Lopez-Gomez and Gomez-Lim, 1992), denatured, fractionated $\left(30 \mu \mathrm{g}\right.$ lane $\left.{ }^{-1}\right)$ and transferred to a Hybond ${ }^{\mathrm{TM}}-\mathrm{N}+$ (Amersham) membrane (Veierskov et al., 1992). The cDNA inserts from pMON9575 (petunia hsp70 cDNA, Winter et al., 1988) and pAPHSP1, a $0.62 \mathrm{~kb}$ full length apple hsp cDNA designated LMW hsp (M. LayYee and J.H. Bowen, unpublished), with 75\% homology to pFS1968, a soybean hsp17 cDNA (Schöffl et al., 1984), were labelled with ${ }^{32} \mathrm{P}$ using a random primers DNA labelling system (BRL). Hybridisation was carried out according to the Amersham Hybond ${ }^{\mathrm{TM}}-\mathrm{N}+$ protocol. Following hybridisation, the membrane was washed twice for $10 \mathrm{~min}$ in $2 \times \mathrm{SSC}, 0.1 \% \mathrm{SDS}$ at room temperature, then once in $1 \times \mathrm{SSC}, 0.1 \% \mathrm{SDS}$ at $65^{\circ} \mathrm{C}$ for $15 \mathrm{~min}$. The membrane was exposed to Kodak XAR film with intensifying screens at $-80^{\circ} \mathrm{C}$. RNA loadings for the membranes were determined by hybridisation with an $18 \mathrm{~S}$ ribosomal probe (Simon and Weedon, 1992). Autoradiographs were processed to quantify the observed homologous signal using densitometry software. Signal intensities were adjusted for differences in RNA loadings, and the normalised values presented as bar graphs.

\subsection{Fruit temperature and chilling and thermotolerance (Expt 2)}

\subsubsection{Fruit}

'Hass' avocado fruit were harvested from a commercial orchard in South Auckland in October (early summer). Fruit temperatures on the tree were monitored as described above, and fruit were sampled at 15:00 h (air temperature of $21^{\circ} \mathrm{C}$ ). For sun fruit, average temperatures were $36.3^{\circ} \mathrm{C}$ for the exposed, and $27.4^{\circ} \mathrm{C}$ for the unexposed sides. Fruit were transported to Mt Albert Research Centre $(1 \mathrm{~h})$, and subjected to hot water, and storage (chilling) treatments.

\subsubsection{Hot water treatments}

Hot water treatments (HWTs) were carried out for $0,1,3,5,7.5$ or $10 \mathrm{~min}$ at $50^{\circ} \mathrm{C}$ in water baths (Woolf and Lay-Yee, 1997). Ten sun, and ten shade fruit were used for each HWT, and fruit were then held at $20^{\circ} \mathrm{C}$ with external damage increasing to a maximum after 5 days; 5 day data only are presented in the results. External damage was rated on a relative scale of $0-3 \quad(0=$ no occurrence, $\quad 0.5=<10 \%, \quad 1.0=\geq 10 \leq 20 \%$, $1.5=\geq 20 \leq 50 \%, 2=\geq 50 \leq 75 \%, \geq 2.5=70 \leq$ $90 \%, 3.0=>90 \%$ of the fruit surface area). All fruit handling, HWTs and fruit ripening were carried out in a controlled environment room $\left(20 \pm 2{ }^{\circ} \mathrm{C} ; \mathrm{RH} 65 \pm 10 \%\right)$.

\subsubsection{Cold storage}

Fruit were placed into storage at $0.5 \pm 0.5^{\circ} \mathrm{C}$ within $1.5 \mathrm{~h}$ of harvest, and samples removed after 9,18 or 28 days. Ten sun and ten shade fruit were used for each storage treatment. External damage was rated using the above scale upon removal from storage.

\subsubsection{Electrolyte leakage}

Three extra fruit were harvested at each of the sampling times to determine the rate of electrolyte leakage from skin disks as described by Woolf (1997). Data resented are the average of three replicates and expressed as percent total conductivity; total conductivity was measured for tissue which had been frozen, thawed and boiled. 


\subsubsection{Shelf life}

Fruit ripeness was determined by firmness, assessed daily by gentle hand-squeezing by one trained assessor. When each fruit became 'ripe to eat', equivalent to a 'firmometer' (Swarts, 1981) reading of ca. 99, the number of days was recorded (shelf life).

\section{Results}

\subsection{Fruit temperature and heat shock response (Expt 1)}

\subsubsection{Fruit temperatures}

Over a 10-day period in mid-summer, even though air temperature never exceeded $25^{\circ} \mathrm{C}$ (average maximum/minimum; $23.0 / 13.4^{\circ} \mathrm{C}$, respectively), flesh temperatures on the exposed side of sun fruit regularly exceeded $35^{\circ} \mathrm{C}$ (Fig. 1a). The fruit monitored were exposed to direct sunlight for at least $4 \mathrm{~h}$ in the hottest period of the day (11:00-15:00 h). The highest flesh temperatures recorded exceeded $43^{\circ} \mathrm{C}$, and the temperature difference across the fruit from exposed to unexposed sides sometimes exceeded $10^{\circ} \mathrm{C}$ (Fig. 1b). Flesh temperatures of shade fruit largely followed air temperatures, except in the later parts of the day, when the flesh temperature rose as much as $2.4^{\circ} \mathrm{C}$ above air temperature (Fig. 1a). Skin temperatures determined using the infrared thermometer, were found to be within $1^{\circ} \mathrm{C}$ of flesh temperature.

\subsubsection{Heat shock proteins}

Protein labelling and RNA extraction were carried out at 12:00, 15:00, 20:00, and 08:00 h, from skin and flesh on the exposed and unexposed sides of sun fruit. All fruit sampled (in duplicate), including that at 12:00 h, had reached flesh and skin temperatures exceeding $35^{\circ} \mathrm{C}$, on the exposed side of the fruit, either at the time of sampling, or in the preceding afternoon (Fig. 1b). When ${ }^{35} \mathrm{~S}-\mathrm{me}-$ thionine-labelled proteins from flesh tissue were separated by 1-D SDS-PAGE, increased labelling in a number of bands was found in response to high temperature exposure (Fig. 2), and the same pattern was found in skin tissue (data not shown).
Newly-labelled, or more strongly-labelled bands are obvious in tissue sampled at 12:00 and 15:00 $\mathrm{h}$, particularly a band at ca. $25 \mathrm{kDa}$, and bands below and above the $80 \mathrm{kDa}$ marker (Fig. 2). The labelling of these bands was lower at the 20:00 h sampling. Another heavily-labelled band just above the $18.5 \mathrm{kDa}$ marker was much stronger in the exposed than in the unexposed tissue.

\subsubsection{Northern analysis}

The levels of hsp RNA increased in both skin (Fig. 3) and flesh tissue with increasing fruit temperature. The levels of RNA homologous to hsp17 cDNA (pAPHSP1) were highest at 15:00 h in the exposed skin tissue. The unexposed tissue also had hsp17 mRNA; the highest levels were at 12:00 $\mathrm{h}$ and thereafter declined. In exposed skin tissue, hsp70 (pMON9575) transcripts also increased to a maximum at 15:00 h (data not shown). There appeared to be a diurnal transcript pattern, the levels being highest at 12:00 h, overlaid by high temperature influence on the exposed side of sun fruit, this being greatest at 15:00 h.

\subsection{Fruit temperature and chilling and thermotolerance (Expt 2)}

\subsubsection{Fruit temperatures}

In the following season, temperatures were logged over a 5-week period in early summer (September/October). The average maximum and minimum air temperatures over this period were 18.5 and $8.1{ }^{\circ} \mathrm{C}$, respectively, and rarely exceeded $21^{\circ} \mathrm{C}$. Flesh temperatures on the exposed side of sun fruit still exceeded $30^{\circ} \mathrm{C}$ and on a number of occasions $35^{\circ} \mathrm{C}$. As found in Expt 1, large temperature differentials between exposed and unexposed sides of sun fruit were observed.

\subsubsection{Heat tolerance-external damage}

Hot water treatments at $50^{\circ} \mathrm{C}$ resulted in skin browning (Fig. 4A), that developed to a maximum 5 days after treatment. External damage of shade fruit increased with duration of HWT above $3 \mathrm{~min}$, with a maximum average severity of 2.6 following a 10 min HWT (Fig. 5). In contrast, the exposed side of sun fruit did not exhibit any external damage following any HWT (sun fruit, 

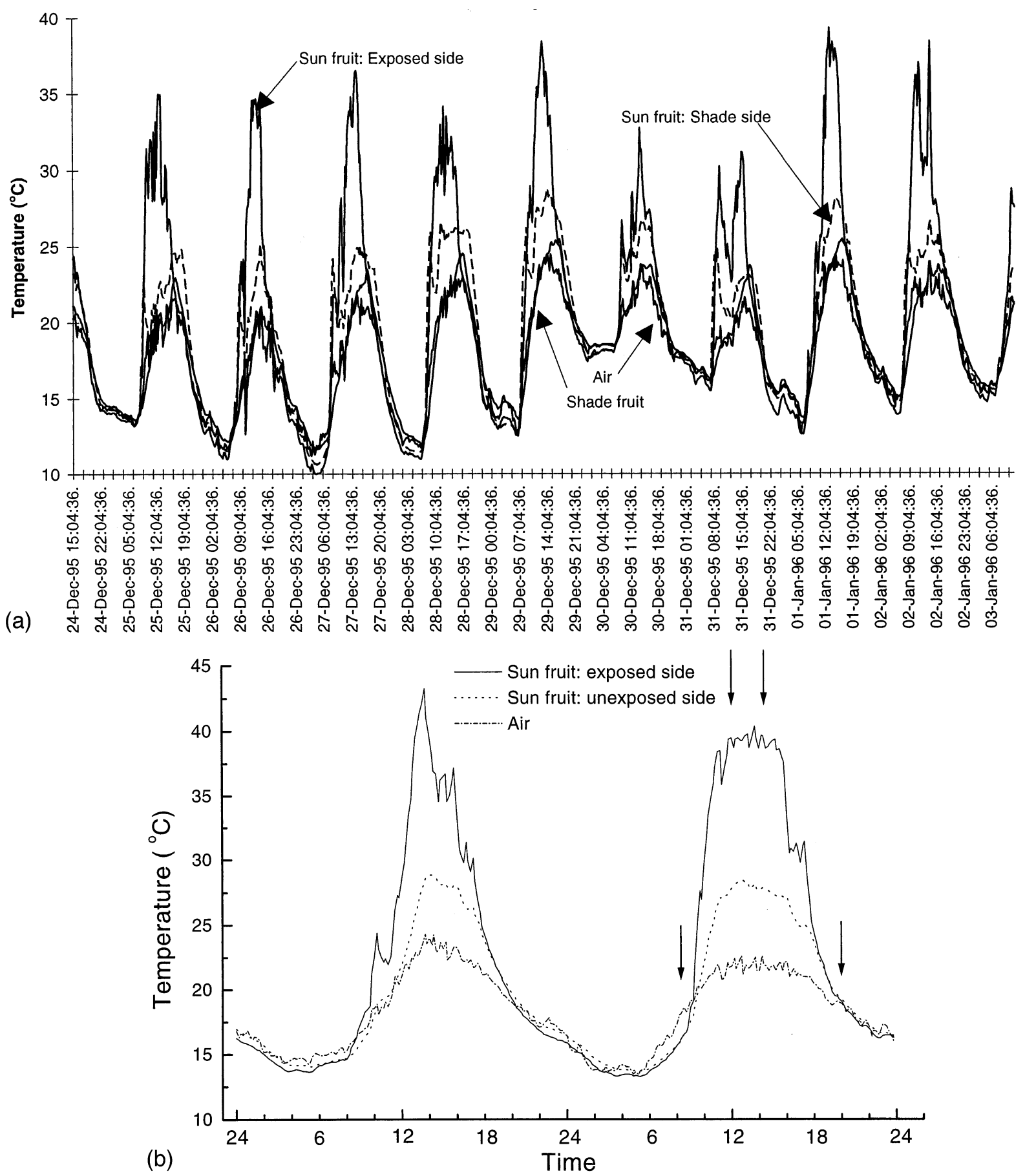

Fig. 1. (a) Temperature profile of exposed and shaded sides of sun fruit (measured $10 \mathrm{~mm}$ into the flesh), and air temperature, over 10 days during mid-summer (December-January). (b) Temperature profile of representative exposed fruit, and air temperature (February 28-29). Arrows indicate when tissue samples were taken for hsp analysis. 


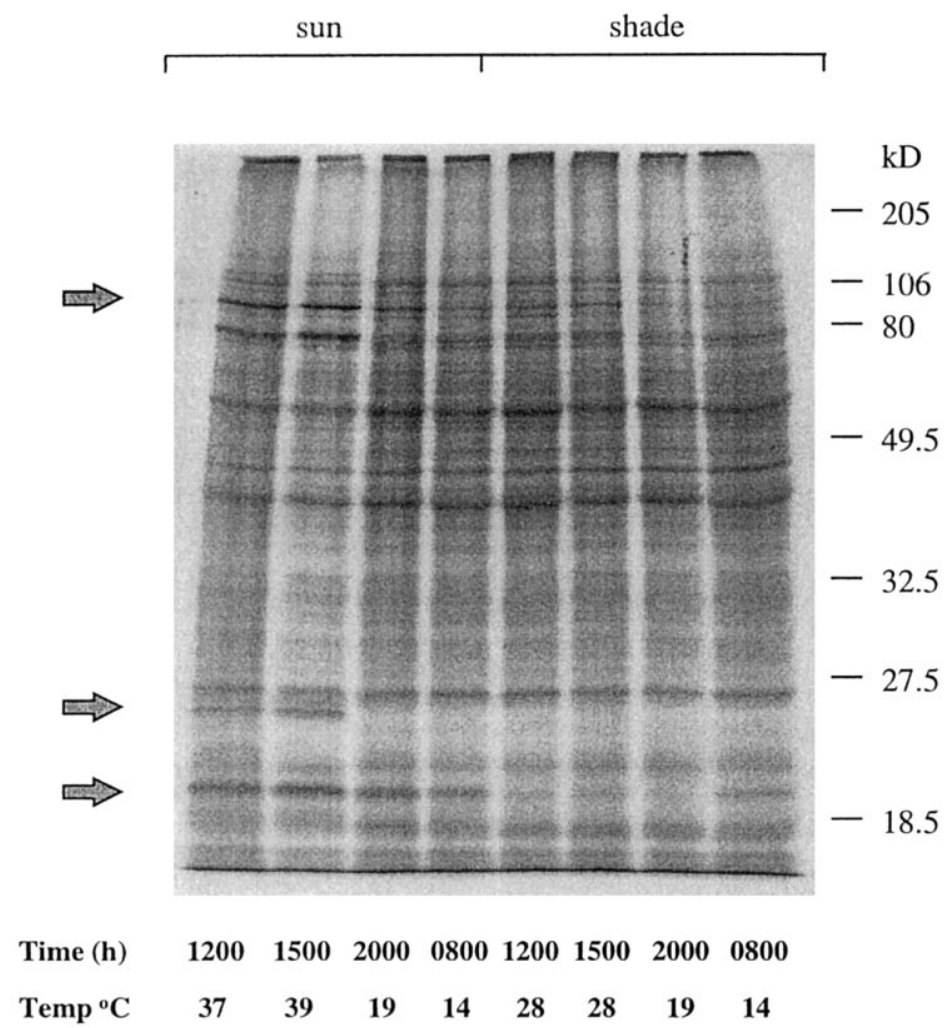

Fig. 2. Separation of avocado fruit proteins radiolabelled with $\left[{ }^{35} \mathrm{~S}\right]$ methionine immediately after picking fruit at various times of the day. Proteins were extracted from flesh tissues of exposed and unexposed sides of sun avocado fruits at the indicated times. Temperatures were those of the fruit at the sampling times. Arrows indicate protein bands that were more heavily labelled with exposure of fruit to high temperatures.

exposed side; Fig. 4C, Fig. 5). However, the unexposed side of the sun fruit (sun fruit, unexposed side; Fig. 4B, Fig. 5) became damaged, although to a lesser extent than shade fruit (severity of 1.8 following a $10 \mathrm{~min}$ HWT).

\subsubsection{Heat tolerance-shelf life}

Sun fruit had a longer shelf life (time to ripening) than shade fruit in all treatments. The difference in shelf life between sun and shaded fruit for the control treatment (non-hot water treated) was 1.6 days, and the average difference for all hot water treatments was $1.3 \pm 0.3$ days.

\subsubsection{Chilling tolerance-external damage}

For the sun fruit, the exposed side of the fruit had almost no damage $(<0.5)$ after 28 days storage at $0.5^{\circ} \mathrm{C}$ (Fig. 4F, Fig. 6A). On the unexposed side of sun fruit, and on the shade fruit, damage was evident after 9 days, and increased with longer duration of storage at $0.5^{\circ} \mathrm{C}$ to a maximum average severity rating of about 2 after 28 days storage (Fig. 4D,E, Fig. 6A).

\subsubsection{Chilling tolerance-electrolyte leakage}

Immediately after harvest (no storage), electrolyte leakage from skin disks taken from exposed side of sun fruit $(16.4 \%)$ was slightly higher than that of shade fruit (14.3\%; Fig. 6B). However, as storage duration increased, leakage from the skin of shade fruit increased to a maximum of about $23 \%$ after $18-28$ days storage, while skin of sun fruit did not change significantly. 

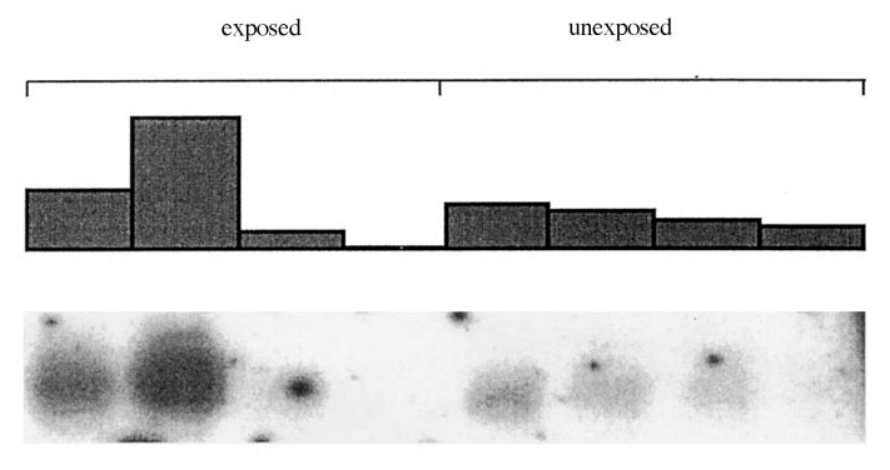

$\begin{array}{lrrrrrrrr}\text { Time (h) } & 1200 & 1500 & 2000 & 0800 & 1200 & 1500 & 2000 & 0800 \\ & & & & & & & & \\ \text { Temp }^{\circ} \mathrm{C} & 38 & 39 & 19 & 14 & 28 & 28 & 19 & 14\end{array}$

Fig. 3. Northern analysis of RNA homologous with pAPHSP1 cDNA (hsp17). Total RNA was extracted from skin of exposed and unexposed sides of sun avocado fruit at the given times. The bar graph shows normalised signal intensities adjusted for differences in RNA loadings. Temperatures were those of the fruit at the sample times.

\section{Discussion}

\subsection{Fruit temperatures}

On the tree, fruit flesh and skin of exposed fruit frequently reached temperatures $10-15^{\circ} \mathrm{C}$ above air temperature. These high fruit temperatures were associated with direct sunlight, suggesting that radiance has the largest impact on fruit temperature. Skin and flesh temperatures above $35^{\circ} \mathrm{C}$ on the exposed side of sun fruit could be maintained for as long as 2-4 h. Where flesh temperatures on the unexposed side of sun fruit reached about $5^{\circ} \mathrm{C}$ above air, this could be due to heat transfer across the fruit, and diffuse or reflected radiation. This temperature gradient across the fruit has been modelled in apple fruit by Thorpe (1974), where under direct irradiation, an $8^{\circ} \mathrm{C}$ difference was found between exposed and unexposed fruit surfaces. This agrees with our finding of a $10^{\circ} \mathrm{C}$ temperature gradient across avocado fruit. The slight increase in flesh temperatures above air in completely shaded fruit was probably due to diffuse radiation throughout the canopy.

The high fruit temperatures found in this study and with apple fruit (Ferguson et al., 1998) occurred under temperate conditions, where maxi- mum air temperatures rarely exceed $30^{\circ} \mathrm{C}$. In hotter, dry climates, such as in Australia and California, fruit such as melons and grapes exposed to the sun can reach temperatures exceeding $40^{\circ} \mathrm{C}$, but air temperatures in these cases are usually above $30^{\circ} \mathrm{C}$ (Schroeder, 1965; Kliewer and Lider, 1968).

\subsection{Tolerance to high and low temperature postharvest treatments}

High temperatures experienced by fruit in the field can have effects on postharvest responses similar to those of postharvest heat treatments. Hot water pretreatments at $38^{\circ} \mathrm{C}$ applied directly after harvest increase tolerance of avocado fruit to $50^{\circ} \mathrm{C}$ HWTs (Woolf and Lay-Yee, 1997). Exposed sides of sun fruit also had greater tolerance to $50^{\circ} \mathrm{C}$ than did unexposed sides of the fruit or shade fruit, in agreement with these postharvest results.

Postharvest high temperatures also reduce chilling injury. Treating 'Hass' avocado fruit at $38^{\circ} \mathrm{C}$ (water; Woolf, 1997), or at $36-40^{\circ} \mathrm{C}$ (hot air; Woolf et al., 1995; Florissen et al., 1996) reduces subsequent chilling injury at low storage temperatures of $0-2^{\circ} \mathrm{C}$. Exposure of avocado fruit to high 


\section{HWT}

A
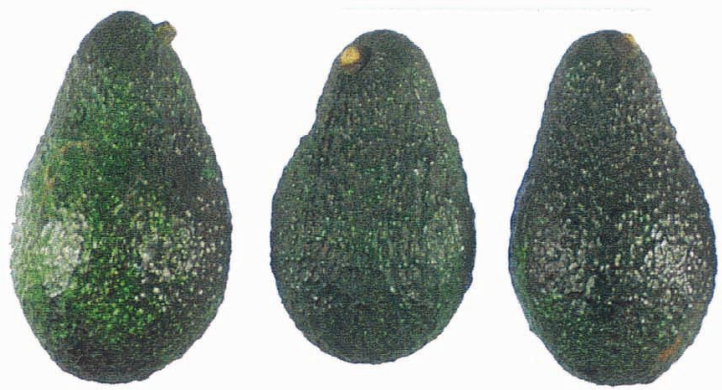

B

\section{Sun fruit Unexposed side}
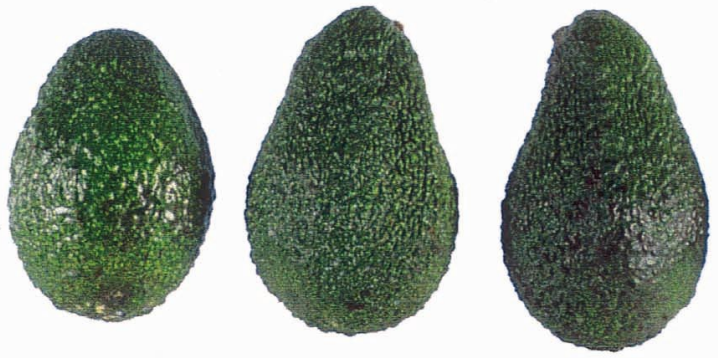

C

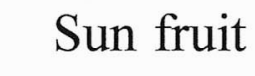
Exposed side
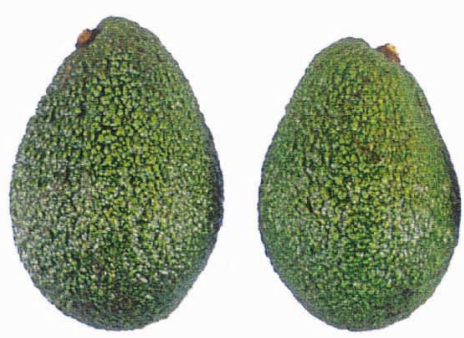

D
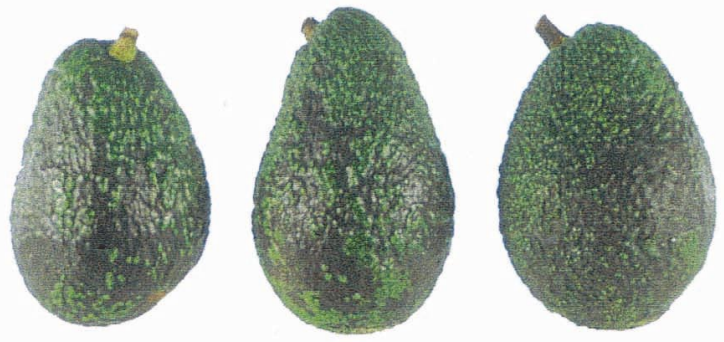

E

Sun fruit

\section{Unexposed side}
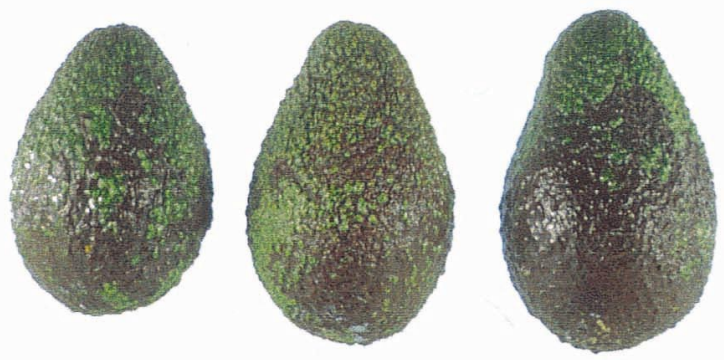

F

Sun fruit

\section{Exposed side}
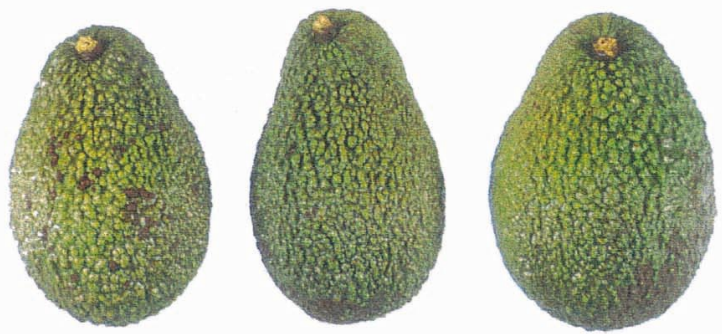

Fig. 4. External appearance of avocado fruit hot water-treated at $50^{\circ} \mathrm{C}$ for $7.5 \mathrm{~min}$ (HWT, A-C), or coolstored for 4 weeks at $0^{\circ} \mathrm{C}$ (CI, D-F). Fruit were harvested from completely shaded portions of the tree (Shade fruit, A and D), or from locations exposed to direct sunlight (sun fruit). For sun fruit, the side of the fruit shaded from the sun (unexposed side, B and E) and the opposite, exposed side of the fruit (exposed side, $\mathrm{C}$ and $\mathrm{F}$ ), are shown. 


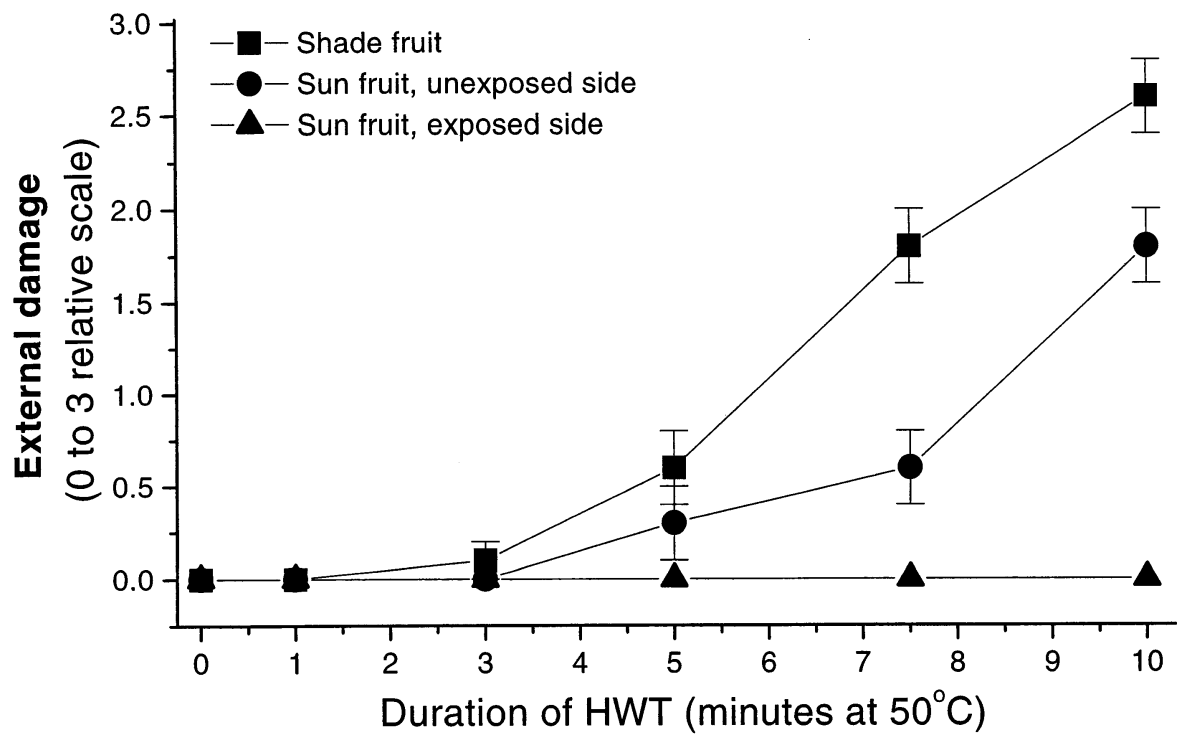

Fig. 5. External damage of shaded avocado fruit, and sun and shaded sides of sun fruit following $50^{\circ} \mathrm{C}$ hot water treatment for 0 (control), 1, 3, 5, 7.5, or $10 \mathrm{~min}$. External damage after 5 days at $20^{\circ} \mathrm{C}$ was rated on a scale of 0 (no damage), to 3 (complete damage). Vertical bars represent S.E.M. values.

temperatures on the tree resulted in a similar reduction in external chilling injury (during storage at $0.5^{\circ} \mathrm{C}$; Fig. $6 \mathrm{~A}$ ). In addition, the concomitant reduction in skin electrolyte leakage in tissues previously exposed to the sun (Fig. 6B) paralleled the reduction in external damage. This relationship between lower leakage and reduced chilling injury was also found with $38^{\circ} \mathrm{C}$ postharvest water treatments (Woolf, 1997).

Skin and flesh tissues reach similar temperatures on the tree, and have similar patterns of hsp induction (see below). Although each tissue manifests different characteristics, the postharvest responses of each tissue was influenced by high temperatures prior to harvest. For example, skin tissue on the exposed side of sun fruit exhibited less chilling injury and heat damage. Flesh tissue shows the influence of high field temperatures in slower fruit ripening (increased shelf life), consistent with previous work where postharvest heat treatments slowed ripening (Woolf et al., 1995; Woolf, 1997). This suggests that variability in shelf life of an avocado fruit population may be due at least in part, to variation in fruit temperatures experienced by fruit growing on the tree in different positions.

\subsection{Hsp response}

Induction of hsps is seen as central to high temperature tolerance in both plants and animals. Heat shock protein gene expression and protein levels increase in response to postharvest heat treatments in avocados (Woolf et al., 1995; Florissen et al., 1996; Woolf and Lay-Yee, 1997), and have been associated with increased tolerance of fruit to potentially damaging heat treatments (e.g. $50^{\circ} \mathrm{C}$ ) induced by pretreatments at $38^{\circ} \mathrm{C}$ (Paull and Chen, 1990; Woolf and Lay-Yee, 1997). The involvement of hsps being involved in protection of fruit against chilling injury has also recently been suggested (Lurie et al., 1993; Woolf et al., 1995; Sabehat et al., 1996), and is extended by the relationship shown here between hsp induction on the tree and postharvest responses. The higher levels of hsp17 homologous mRNA in the skin of the exposed side of sun fruit relative to unexposed sides (Fig. 3) suggest responses to heat similar to those of hsp induction by water and hot air postharvest treatments. This stimulation of hsp production in fruit on the tree may increase tolerance of these exposed tissues to postharvest heat tolerance, and possibly also to increased low temperature tolerance. 


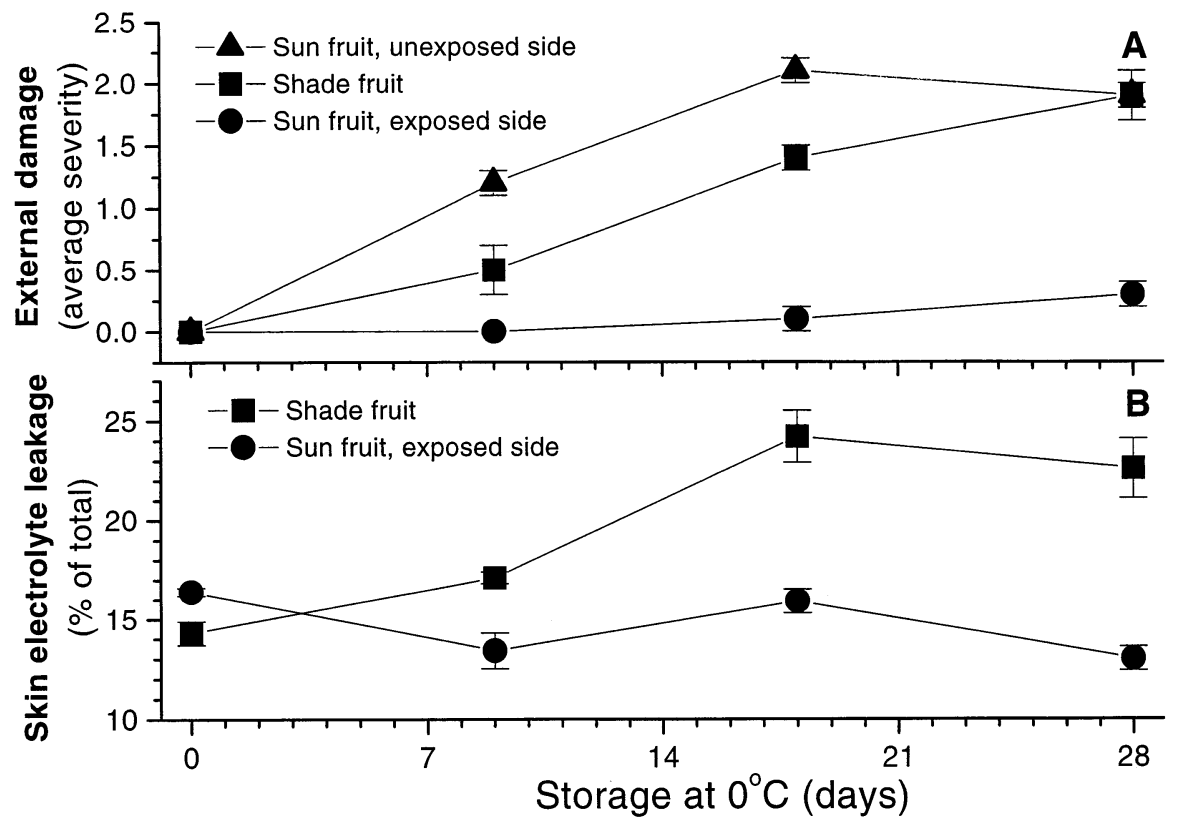

Fig. 6. Fruit response of sun and shaded avocado fruit following storage at $0.5^{\circ} \mathrm{C}$ for up to 28 days. (A) External damage of shaded fruit, and sun and shaded sides of sun fruit immediately following storage. Damage was rated on a scale of 0 (no damage), to 3 (complete damage). (B) Electrolyte leakage from disks of skin from the exposed side of sun fruit, and from skin disks from shaded fruit during storage at $0.5^{\circ} \mathrm{C}$. Leakage was expressed as percentage of the total leakage. Vertical bars represent S.E.M. values.

In apple fruit, hsp gene expression followed diurnal temperature cycles, peaking $1-2 \mathrm{~h}$ after the maximum afternoon temperature, and remaining up-regulated through the night when temperatures declined. Transcript levels dropped markedly as fruit warmed up from overnight temperatures during the morning, increasing again with the next high temperature period the following afternoon (Ferguson et al., 1998). This is a normal homeostatic response to large temperature fluctuations, and our data suggest that similar responses are found in avocado fruit.

\subsection{Postharvest implications}

Avocado fruit may be repeatedly exposed to high temperatures during the season. The postharvest responses associated with fruit exposure were observed on fruit harvested at high temperatures $(15: 00 \mathrm{~h})$. However, there may be long-term effects, where postharvest responses reflect high temperatures experienced repeatedly through the season. Long-term, frequent high temperature exposure may result in accumulation of both morphological and physiological features that differ from those of shade fruit, or the unexposed side of sun fruit. Short-term effects are more likely to result from biochemical or physiological responses to high temperature close to the time of harvest. Separation of longterm from short-term effects requires fruit to be harvested from different fruiting (exposure) sites at different times of the day, or at different temperatures, or manipulation of fruit exposure.

Between-fruit variability in response to postharvest treatments and handling conditions is a key problem for industry and researchers. We have shown that a possible reason for this variability is the effect of different preharvest temperature histories on both tolerance to postharvest temperature treatments, and rate of ripening. 


\section{Acknowledgements}

We wish to thank Ross Ferguson and Dave Turner for the fruit and the Lotteries Board for an equipment grant. This work was funded by the NZ Foundation for Research, Science and Technology, Contract No. CO6429.

\section{References}

Ferguson, I.B., Lurie, S., Bowen, J.H., 1994. Protein synthesis and breakdown during heat shock in cultured pear cells. Plant Physiol. 104, 1429-1437.

Ferguson, I.B., Snelgar, W., Lay-Yee, M., Watkins, C.B., Bowen, J.H., 1998. Heat shock response in apple fruit in the field. Aust. J. Plant Physiol. 25, 155-163.

Florissen, P., Ekman, J.S., Blumenthal, C., McGlasson, W.B., Condroy, J., Holford, P., 1996. The effects of short heattreatments on the induction of chilling injury in avocado fruit (Persea americana Mill.). Postharvest Biol. Technol. 8, 129-141.

Jacobi, K.K., Giles, J.E., 1997. Quality of 'Kensington' mango (Mangifera indica Linn.) fruit following combined vapour heat disinfestation and hot water disease control treatments. Postharvest Biol. Technol. 12, 285-292.

Kliewer, M.W., Lider, L.A., 1968. Influence of cluster exposure to the sun on the composition of Thompson seedless fruit. Am. J. Enol. Viticult. 19, 175-184.

Lopez-Gomez, R., Gomez-Lim, M.A., 1992. A method for extracting intact RNA from fruits rich in polysaccharides using ripe mango mesocarp. HortScience 27, 440-442.

Lurie, S., Klein, J.D., 1991. Acquisition of low-temperature tolerance in tomatoes by exposure to high-temperature stress. J. Am. Soc. Hort. Sci. 116, 1007-1012.

Lurie, S., Klein, J.D., Watkins, C.B., Ross, G.S., Boss, P.K., Ferguson, I.B., 1993. Prestorage heat treatments of tomatoes prevent chilling injury and reversibly inhibit ripening. Acta Hort. 343, 283-285.
Paull, R.E., 1995. Preharvest factors and the heat sensitivity of field-grown ripening papaya fruit. Postharvest Biol. Technol. 6, 167-175.

Paull, R.E., Chen, N.J., 1990. Heat shock response in fieldgrown, ripening papaya fruit. J. Am. Soc. Hort. Sci. 115, $623-631$.

Sabehat, A., Weiss, D., Lurie, S., 1996. The correlation between heat-shock protein accumulation and persistence and chilling tolerance in tomato fruit. Plant Physiol. 110, 531-537.

Sanxter, S.S., Nishijima, K.A., Chan, H.T. Jr., 1994. Heattreating 'Sharwil' avocado for cold tolerance in quarantine cold treatments. HortScience 29, 1166-1168.

Schöffl, F., Raschke, E., Hagao, R.T., 1984. The DNA sequence analysis of soybean heat-shock genes and identification of possible regulatory promoter elements. EMBO J. 3, 2491-2497.

Schroeder, C.A., 1965. Temperature relationships in fruit under extreme conditions. Proc. Am. Soc. Hort. Sci. 87, 199-203.

Simon, C.J., Weedon, N.F., 1992. Molecular analysis and cloning of Malus ribosomal DNA. J. Am. Soc. Hort. Sci. 117, 164-168.

Swarts, D.H., 1981. The Firmometer-for monitoring ripening of avocados (and other fruit). S. African Avocado Growers Assoc. 4, 42-46.

Thorpe, M.R., 1974. Radiant heating of apples. J. Appl. Ecol. 11, 755-760.

Veierskov, B., Ferguson, I.B., Lay-Yee, M., 1992. Conjugation of ubiquitin to proteins during greening of etiolated oat plants. J. Plant Physiol. 139, 749-754.

Winter, J., Wright, R., Duck, N., Gasser, C., Fraley, R., Shah, D., 1988. The inhibition of petunia hsp70 mRNAs processing during $\mathrm{CdCl}_{2}$ stress. Mol. Gene Genet. 211, 315-319.

Woolf, A.B., 1997. Reduction of chilling injury in stored 'Hass' avocado fruit by $38^{\circ} \mathrm{C}$ water treatments. HortScience 32, $1247-1251$.

Woolf, A.B., Lay-Yee, M., 1997. Pretreatments at $38^{\circ} \mathrm{C}$ of 'Hass' avocado confer thermotolerance to $50^{\circ} \mathrm{C}$ hot-water treatments. HortScience 32, 705-708.

Woolf, A.B., Watkins, C.B., Bowen, J.H., Lay-Yee, M., Maindonald, J.H., Ferguson, I.B., 1995. Reduction of external chilling injury in stored 'Hass' avocado fruit by dry heat treatments. J. Am. Soc. Hort. Sci. 120, 1050-1056. 